Article

\title{
Distribution of carbon and nitrogen and ecological stoichiometry of the plant-litter-soil continuum in an evergreen broad-leaved forest
}

\author{
Hui Wang ${ }^{1}$, Bing Wang ${ }^{1,2,3,}$, , Xiang Niu ${ }^{1,2,3,}$, Qingfeng Song ${ }^{1}$, Haonan Bai ${ }^{4}$, Yueqiao Li ${ }^{5}$, \\ Jiadong Luo ${ }^{5}$, Hedong Chen ${ }^{5}$, Linya Nie ${ }^{5}$, Zhiwei Luo ${ }^{5}$ \\ 1 Institute of Forest Ecology, Environment and Protection, Chinese Academy of Forestry, Beijing 100091, \\ China; wh244828129@sina.com \\ 2 Key Laboratory of Forest Ecology and Environment, State Forestry Administration, Beijing 100091, China \\ 3 Beijing Forestry Fruit Industry Eco-environment Enhancement Collaborative Innovation Center, Beijing \\ 102206, China \\ 4 Research Center for Terrestrial Biodiversity of the South China Sea, Hainan University, Haikou 570228, \\ China; 228272655@qq.com \\ 5 Experimental Center for Subtropical Forestry, Chinese Academy of Forestry, Fenyi 336600, Jiangxi, P.R. \\ China; 575886548@qq.com \\ * Correspondence: wangbingcfern@163.com (B. W.); niuxiang@caf.ac.cn (X. N.); Tel.: +86-136-0120-4579 (B. \\ W.); +86-134-2642-4241 (X. N.)
}

\begin{abstract}
We analyzed the plant-litter-soil continuum to investigate the carbon and nitrogen distribution and ecological stoichiometry of an evergreen broad-leaved forest at Dagangshan Mountain, Jiangxi. The results showed that the average $\mathrm{C}$ and $\mathrm{N}$ contents and C:N ratios in the leaves and fine roots among 6 different tree species were $401.87 \mathrm{~g} / \mathrm{kg}, 21.41 \mathrm{~g} / \mathrm{kg}, 19.27$ and $348.64 \mathrm{~g} / \mathrm{kg}, 15.73 \mathrm{~g} / \mathrm{kg}, 23.97$, respectively; the average $\mathrm{C}$ and $\mathrm{N}$ contents and $\mathrm{C}: \mathrm{N}$ ratios were 323.06 $\mathrm{g} / \mathrm{kg}, 12.76 \mathrm{~g} / \mathrm{kg}, 25.58$ respectively in leaf litter, and $16.40 \mathrm{~g} / \mathrm{kg}, 1.09 \mathrm{~g} / \mathrm{kg}, 16.27$ respectively for soil. In contrast with the $\mathrm{C}$ content, the total $\mathrm{N}$ content of the fine roots and litter had a high coefficient of variation and a high spatial heterogeneity. We ranked the six different representative tree species according to total $\mathrm{C}$ and $\mathrm{N}$ content in leaves and fine roots. The results for each species were generally consistent with each other, showing a positive correlation relationship between total $\mathrm{C}$ and $\mathrm{N}$ content in the leaves and roots. Among them, S. discolor (Champ. ex Benth.) Muell. plants displayed high carbon and nitrogen storage capacities, and on the other hand, C. fargesii Franch., C. myrsinifolia (Blume) Oersted, A. fortunei (Hemsl.) Makino, and V. fordii (Hemsl.) Airy Shaw showed a high nitrogen transfer rate. Total soil $\mathrm{N}$ and $\mathrm{C}$ decreased with depth. Soil organic carbon (SOC), soil resistant organic carbon (ROC), total $\mathrm{N}$, alkali nitrogen, $\mathrm{NH}^{+}-\mathrm{N}$ and NO3- $\mathrm{N}$ contents were all also negative correlated with soil depth, but the contents of the $\mathrm{NH}^{+}-\mathrm{N}$ and NO3--N did not change significantly; The spatial distribution of soil NO3-N was significantly heterogeneous. At 0-10 cm soil depth, SOC was positively correlated with alkaline nitrogen, and at 10-20 cm soil depth, SOC was significantly positively correlated with total N. In general, when soil carbon was abundant, nitrogen supply capacity was also high.
\end{abstract}

Keywords: ecological chemometrics 1; carbon cycle 2; nitrogen cycle 3; carbon and nitrogen distribution 4; plant leaf-litter-soil continuum 5

\section{Introduction}

Earth's ecosystems are changing at a global scale. Much of this change is caused by human activities. These changes have been exacerbated by increased technological and economic developments since the industrial revolution, and by rapid population growth since the Second World War. The structure of terrestrial ecosystems, and patterns in vegetation distribution in particular, are the result of long-term climate effects, and as such are at risk of change due to human 
activities. In-depth understanding of ecological processes and dynamics of nutrient cycling, in particular the carbon cycle and nitrogen cycle in terrestrial ecosystems, can provide a scientific basis with which to solve major global problems such as climate change and biodiversity loss [1]. These two cycles are closely linked through a series of material and energy transfer processes in the soilplant-atmosphere system [2]. They are coupled together by a series of biochemical oxidation and reduction reactions. The stability of this coupling is not only affected by the quantitative balance between resource supply and demand, but also by biological factors related to resource utilization and efficiency of transformation [3].

Ecological chemometrics is a discipline that studies the relationship between multiple chemical elements during ecological processes [4]. By combining the basic principles of biology, chemistry and physics, the stoichiometric relationships serve as a means to integrate the different scales of the microand macro-worlds, providing links between individuals, populations, communities and ecosystems. This strategy has been successfully used to explore the balance between nutrients, energy and multiple chemical elements inside an ecosystem [5-6]. Since Elser first proposed ecological chemometrics [4], the discipline has expanded from studying highly stable aquatic ecosystems to terrestrial ecosystems with a wide range of stoichiometric characteristics. Eco-chemochemistry unifies the differently scaled components of ecological entities at the elemental level by measuring carbon, nitrogen and phosphorus contents and calculating their ratios. By doing this, we can better clarify the interactions among ecosystem components and the dynamic balance of chemicals in the process. An ecosystem's composition, function, and response to environmental changes can also be assessed using stoichiometric relationships. The relative abundance of different chemical components of the ecosystem can control the rate of nutrient cycling and energy flow; thus, we can simply use the ratio of elements to reveal the relationship between carbon and nitrogen cycles in an ecosystem, as well as the constraints and regulations of carbon and nitrogen in the process of mass transfer [4, 7-8]. The carbon and nitrogen cycles both transfer elements between plants, litter and soil. Using plant-litter-soil as a complete continuum, the carbon and nitrogen content and ratios of leaves, litter, and soil in the biome can reveal the interaction between elements and the relationship between material balance and constraints in the chemical process [3].

The humid subtropical southern region of China contains the most concentrated area of evergreen broad-leaved forests in the world. Throughout its evolutionary history, the evergreen broad-leaved forest has evolved into a complex, multi-species broad-leaved forest composed mainly of evergreen trees from families such as Fagaceae, Lauraceae, and Theaceae. This type of forest has a complex functional structure, high amount of biomass, and is rich in biodiversity, and thus is a valuable concentration of biological resources in the area [9]. $\mathrm{C}$ and $\mathrm{N}$ are essential nutrients for plant production. In addition, their stoichiometry is indicative, to some degree, of plant growth and development, and therefore of life history and survival strategies [10]. In this study, we treat the plant-litter-soil continuum as one complex object. We investigated the C:N ratios in the plant-littersoil continuum in representative tree species of the evergreen broad-leaved forest. By studying the characteristics of C:N ratios in litter, fine roots and soil, we attempted to understand: 1. the carbon and nitrogen stoichiometry of each core component of an evergreen broad-leaved forest ecosystem; 2. the interaction between $\mathrm{C}$ and $\mathrm{N}$; and 3. the principle of their antagonistic dynamics.

\section{Materials and Methods}

\subsection{Overview of the study area}

The study area is located in the Dagangshan National Forest Ecological Station $\left(114^{\circ} 30^{\prime} \sim 114^{\circ} 45^{\prime} \mathrm{E}, 27^{\circ} 30^{\prime} \sim 27^{\circ} 50^{\prime} \mathrm{N}\right)$ in Xinyu City, Jiangxi Province (see Fig. 1). The soil type in this area is Kandiudults, whose main clay mineral is kaolinite. In the study area, the vertical zonal change with altitude is not obvious, and the soil remains very moist, loose, and has a thick humus layer. The maximum elevation is $1091.8 \mathrm{~m}$ above sea level.

The area is of a subtropical monsoon humid climate with low mountain terrain. The average annual temperature of this area is $16.8^{\circ} \mathrm{C}$ and reaches highs of $39.9^{\circ} \mathrm{C}$ and lows of $-8.3^{\circ} \mathrm{C}$. The annual 
average solar radiation of this area is $486.6 \mathrm{KJ} / \mathrm{cm} 2$; annual average relative humidity is $81 \%$; annual average evaporation is $1503 \mathrm{~mm}$; annual precipitation is $1593.7 \mathrm{~mm}$ with rainfall mostly concentrated in the period from April to June. The average annual frost-free period is 268 days. Soils in the area are zonal low hilly red soil, yellow soil and their sub-categories. The yellow soil is widely distributed, mainly at an altitude of 300-700 m; the red soil is mostly distributed in low hills (200 m above sea level). The $\mathrm{pH}$ value of the soil ranges from 4.0 5.0. The percentage of forest cover of this area is $76.4 \%$, and the vegetation is mainly natural secondary evergreen broad-leaved forest, deciduous broad-leaved forest, various coniferous and broad-leaved mixed forest, bamboo forest, Chinese fir plantation, and natural evergreen broadleaf forest. The forest is mainly distributed at an altitude of $600 \mathrm{~m}$ or lower.

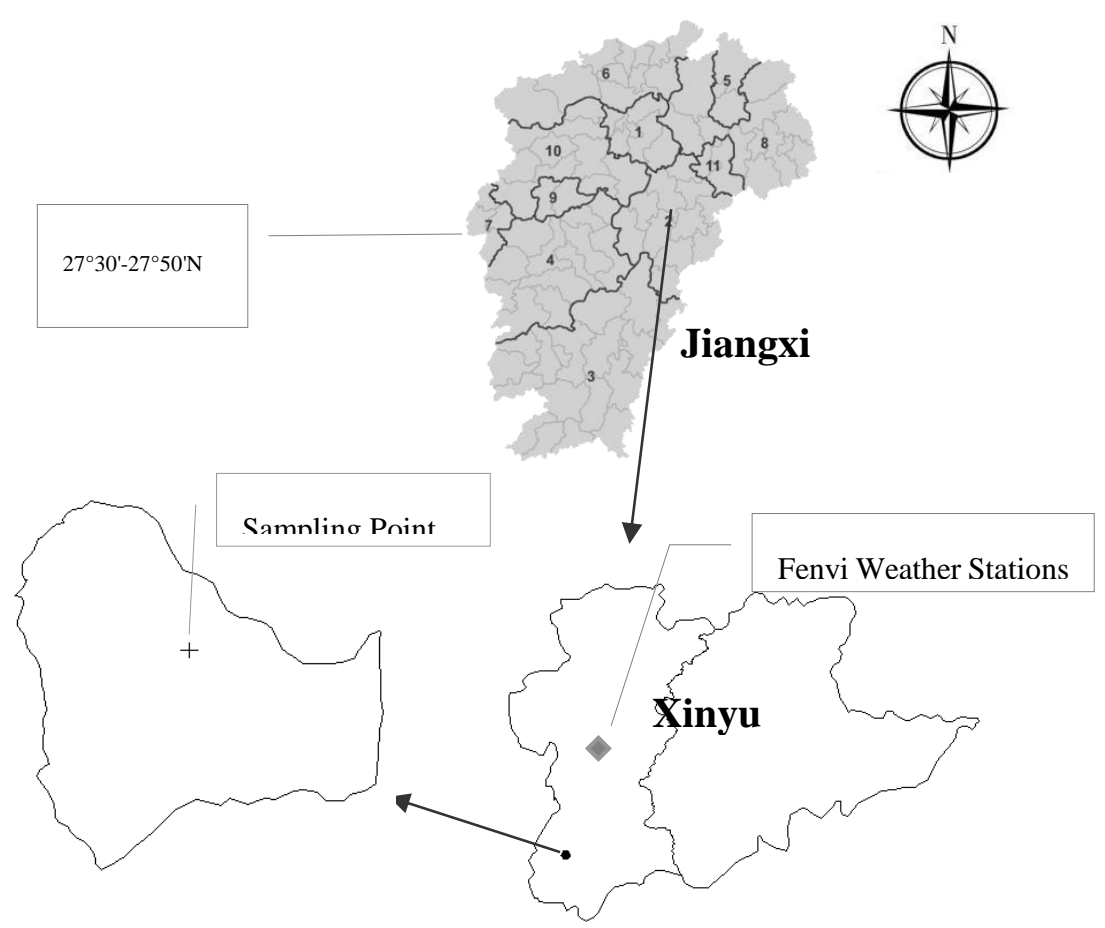

Figure 1. The location of the study area

\subsection{Methods and the collection of samples}

\subsubsection{Collection of soil, litter and plant leaf samples}

Three sampling sites (each $20 \mathrm{~m} \times 20 \mathrm{~m}$ ) in the evergreen broad-leaved forest were randomly selected in Dagangshan, Jiangxi Province (see Table 1). Inside each site, five sampling points (each $1 \mathrm{~m} \times 1 \mathrm{~m})$ were randomly selected, and samples $(50 \mathrm{~cm}$ in diameter) from two layers of soil $(0-10 \mathrm{~cm}$ and $10-20 \mathrm{~cm}$ ) were taken using a soil drill. Subsequently, the soil sampled from different points in each layer were thoroughly mixed for indoor measurement of the soil organic carbon (SOM), soil oxidizable organic carbon (ROC), soil total nitrogen $(\mathrm{N})$, alkaline nitrogen (Alkaline $\mathrm{N}$ ), soil ammonium nitrogen $\left(\mathrm{NH}_{4}{ }^{+}-\mathrm{N}\right)$, and soil nitrate nitrogen $\left(\mathrm{NO}_{3}^{-}-\mathrm{N}\right)$ content.

To measure the total carbon and total nitrogen contents in each $20 \mathrm{~m} \times 20 \mathrm{~m}$ site, we randomly selected five sampling points $(1 \mathrm{~m} \times 1 \mathrm{~m})$ and collected litter (dry weight $1175.85 \mathrm{~g})$ using a bracket made from nylon gauze. The samples were then mixed together in a Kraft paper bag. They were dried in the oven at $105^{\circ} \mathrm{C}$ for $15 \mathrm{~min}$, and then at $80^{\circ} \mathrm{C}$ until sample weight was constant. The sample was then ground into a powder of $0.10 \mathrm{~mm}$ by a pulverizer before the total carbon and total nitrogen contents of the sample were measured. Samples were collected in November 2017 and sample sites are shown in Table 1.

The leaves were collected in November 2017. Six representative species of evergreen broadleaved forest were selected; they are: Sapium discolor (Champ. ex Benth.) Muell., Castanopsis fargesii 
Franch., Cyclobalanopsis myrsinifolia (Blume) Oersted, Machilus pauhoi Kanehira, Alniphyllum fortunei (Hemsl.) Makino, and Vernicia fordii (Hemsl.) Airy Shaw. For each species, we randomly selected three healthy plants from which to collect the mature leaves in the middle and upper parts of the plant facing four directions (i.e., north, east, south, and west). The collected samples were brought back to the laboratory to pretreat and determine the carbon and nitrogen content. To collect fine root samples, the soil underneath these plants ( $2 / 3$ canopy) was collected using a soil drill, and then mixed in a Kraft paper bag. These soil samples were rinsed with running water using a sieve with a pore size of $0.5 \mathrm{~mm}$ to leave the fine roots. The fine root samples were then placed in a $65^{\circ}$ oven, dried to constant weight, and the sample was ground into a $0.10 \mathrm{~mm}$ powder by a pulverizer before measuring the total carbon and total nitrogen content.

Table 1. Basic condition of sample plots and samples of evergreen broad-leaved forest

\begin{tabular}{|c|c|c|c|c|c|c|c|c|c|}
\hline Number & Longitude & Latitude & $\begin{array}{c}\text { Altitude } \\
\text { (m) }\end{array}$ & $\begin{array}{l}\text { Slope } \\
\text { () }\end{array}$ & $\begin{array}{c}\text { Slope } \\
\text { position }\end{array}$ & Aspect & $\begin{array}{c}\text { Height } \\
\text { (m) }\end{array}$ & $\begin{array}{c}\text { Breat } \\
\text { diameter } \\
(\mathrm{cm})\end{array}$ & $\begin{array}{l}\text { Canopy } \\
\text { closure }\end{array}$ \\
\hline 1 & $114^{\circ} 33^{\prime} 42^{\prime \prime}$ & $27^{\circ} 35^{\prime} 12^{\prime \prime}$ & 348 & 22 & Middle & Northwestern & 14.58 & 22.36 & 0.7 \\
\hline 2 & $114^{\circ} 33^{\prime} 38^{\prime \prime}$ & $27^{\circ} 35^{\prime} 11^{\prime \prime}$ & 367 & 15 & Middle & Eastern Slope & 16.26 & 24.21 & 0.7 \\
\hline 3 & $114^{\circ} 33^{\prime} 47^{\prime \prime}$ & $27^{\circ} 35^{\prime} 17^{\prime \prime}$ & 298 & 15 & Middle & Eastern Slope & 11.7 & 20.6 & 0.8 \\
\hline
\end{tabular}

\subsubsection{Analysis indices and measuring methods}

The content of organic carbon in plant leaves, litter, fine roots and soil was determined using the Walkley-Black chromic acid wet oxidation method. To determine the total nitrogen content, plant leaves, litter and fine root samples were digested by $\mathrm{H}_{2} \mathrm{SO}_{4}-\mathrm{H}_{2} \mathrm{O}_{2}$, and the resulting solutions was analyzed using a Kjeldahl nitrogen analyzer (KDY-9380). To determine the total nitrogen in the soil, a sulfuric acid-mixed catalyst was first used, and then the nitrogen content in the digested solution was determined by a Kjeldahl nitrogen analyzer (KDY-9380). Soil ammonium nitrogen $\left(\mathrm{NH}_{4}{ }^{+} \mathrm{N}\right)$ and nitrate nitrogen $\left(\mathrm{NO}_{3}{ }^{-} \mathrm{N}\right)$ content was measured using a continuous flow analyzer (SKALAR San++ continuous flow analyzer). Soil alkaline nitrogen was measured using the diffusion method [11].

\subsection{Data processing}

The $\mathrm{C}$ and $\mathrm{N}$ contents of the leaves, fine roots and collected litter of the representative tree species were all presented as mass percentage, and C: $\mathrm{N}$ ratios were presented as elemental mass ratio. We calculated Pearson's correlation coefficient to assess correlation between C:N ratios in leaves, fine roots, litter and soil from different layers and different trees, and we used One-way ANOVA (Turkey) to assess significance in differences between each category. Statistical analysis was carried out using SPSS 20.0 software $(\alpha=0.05)$.

\section{Results}

\section{1. $C$ and $N$ contents and their ecological stoichiometry in the leaf-litter-soil continuum}

The average $\mathrm{C}$ and $\mathrm{N}$ content of the leaves in the different components were the highest, and the average $\mathrm{C}$ and $\mathrm{N}$ contents in the soil were the lowest. The C:N ratio of the litter was highest. Oneway ANOVA showed that there was no significant difference in average $\mathrm{C}$ and $\mathrm{N}$ content between plant leaves, fine roots and litter for these six representative species. However, there was a significant 
difference in soil $\mathrm{C}$ and $\mathrm{N}$ content between the two layers. As shown in Table 2, the average coefficient of variation $(\mathrm{CV})$ of the average content of $\mathrm{N}$ in the fine roots and litter were significant $(13.33 \%$ and $16.22 \%$, respectively). The average C: $\mathrm{N}$ ratio of leaves is smaller than the $\mathrm{C}: \mathrm{N}$ ratio of the litter, which is probably due to the resorption of the leaves by the plants themselves (Table 3). It is worth noting that the average resorption rate of $\mathrm{N}$ is $40.40 \%$.

Table 2. Average leaf, litter, fine root and soil C and N content of six representative tree species in Dagangshan, Jiangxi Province

\begin{tabular}{|c|c|c|c|}
\hline & $C(g \cdot k g-1)$ & $N(g \cdot k g-1)$ & $C: N$ \\
\hline \multirow[t]{2}{*}{ Leaf } & $401.87(20.56)$ & $21.41(1.75)$ & $19.27(2.58)$ \\
\hline & $349.71-489.78$ & $16.72-27.00$ & $14.97-23.33$ \\
\hline \multirow[t]{2}{*}{ Fine root } & 348.64(11.64) & $15.73(2.09)$ & $23.97(1.12)$ \\
\hline & $318.55-384.92$ & $10.06-22.50$ & $17.11-34.24$ \\
\hline \multirow[t]{2}{*}{ Litter } & $323.06(20.35)$ & $12.76(2.07)$ & $25.58(2.52)$ \\
\hline & $302.72-343.41$ & $11.34-15.13$ & $22.69-27.36$ \\
\hline \multirow[t]{2}{*}{ Soil } & $16.40(1.02)$ & $1.09(0.10)$ & $16.27(1.22)$ \\
\hline & 15.32-17.34 & $0.98-1.16$ & $15.44-17.67$ \\
\hline
\end{tabular}

Note: Numbers in the parentheses are standard deviation.

Table 3. The P-values of average leaf, litter, fine root and soil C and $\mathrm{N}$ content of six representative tree species in Dagangshan, Jiangxi Province

\begin{tabular}{ccccc}
\hline $\mathbf{P}(\mathbf{C} / \mathbf{N})$ & Litter & Leaf & Fine root & Soil \\
\hline Litter & - & 0.1816 & 0.1515 & $0.0023^{*}$ \\
Leaf & 0.3528 & - & 0.4226 & $0.0005^{*}$ \\
Fine root & 0.3177 & 0.4465 & - & $0.0004^{*}$ \\
Soil & & & & \\
\hline
\end{tabular}

Note: Less than 0.05 is significant difference. 


\section{2. $C$ and $N$ content and ecological stoichiometry of different plant leaves and fine roots}

For the representative species of the evergreen broad-leaved forest in the study area, according to the average $C$ content of the leaves, $C$. myrsinifolia had a significantly higher average $C$ content than the other 5 species, and the average $C$ contents of $S$. discolor and $V$. fordii were significantly higher than those of $C$. fargesii, $A$. fortune and $M$. pauhoi. The average $N$ contents of $C$. myrsinifolia and $V$. fordii were significantly higher than $S$. discolor and $C$. fargesii. The $\mathrm{C}: \mathrm{N}$ ratios of $S$. discolor and $C$. fargesii were significantly higher than $V$. fordii and $A$. fortunei (Table 4).

M. pauhoi and $S$. discolor had the highest average $C$ content in fine roots, and the average $C$ contents of roots in C. fargesii and C. myrsinifolia were significantly higher than those of $A$. fortune and $V$. fordii. M. pauhoi and $S$. discolor had the highest average $\mathrm{N}$ content in fine roots. The C:N ratios of $C$. fargesii and C. myrsinifolia were significantly higher than those of S. discolor and M. pauhoi.

Table 4. Contents of carbon and nitrogen in leaves and fine roots of six species of evergreen broad-leaved forest in Dagangshan Mountain, Jiangxi Province

\begin{tabular}{ccccccc}
\hline & & \multicolumn{3}{c}{ leaves } & & \multicolumn{3}{c}{ fineots } \\
& $\mathbf{C ~ g} / \mathbf{k g}$ & $\mathbf{N ~ g} / \mathbf{k g}$ & $\mathbf{C}: \mathbf{N}$ & $\mathbf{C ~ g} / \mathbf{k g}$ & $\mathbf{N ~ g} / \mathbf{k g}$ & $\mathbf{C : N}$ \\
\hline \multirow{2}{*}{$\mathrm{SD}$} & $418.16 \mathrm{c}$ & $17.92 \mathrm{a}$ & $23.33 \mathrm{~b}$ & $381.82 \mathrm{c}$ & $20.67 \mathrm{~b}$ & $18.47 \mathrm{a}$ \\
& $(3.14)$ & $(1.02)$ & $(4.40)$ & $(1.65)$ & $(1.27)$ & $(1.30)$ \\
$\mathrm{CF}$ & $384.83 \mathrm{~b}$ & $16.72 \mathrm{a}$ & $23.01 \mathrm{~b}$ & $344.49 \mathrm{~b}$ & $10.06 \mathrm{a}$ & $34.24 \mathrm{c}$ \\
& $(3.33)$ & $(1.20)$ & $(2.47)$ & $(1.48)$ & $(1.53)$ & $(5.15)$ \\
$\mathrm{CM}$ & $489.78 \mathrm{~d}$ & $24.44 \mathrm{c}$ & $20.04 \mathrm{ab}$ & $338.18 \mathrm{~b}$ & $10.67 \mathrm{a}$ & $31.69 \mathrm{bc}$ \\
& $(2.23)$ & $(1.57)$ & $(1.42)$ & $(1.33)$ & $(1.06)$ & $(3.39)$ \\
$\mathrm{MP}$ & $349.71 \mathrm{a}$ & $18.22 \mathrm{ab}$ & $19.2 \mathrm{a}$ & $384.92 \mathrm{c}$ & $22.5 \mathrm{~b}$ & $17.11 \mathrm{a}$ \\
& $(3.34)$ & $(0.74)$ & $(4.53)$ & $(1.25)$ & $(1.74)$ & $(1.48)$ \\
& $361.3 \mathrm{a}$ & $24.14 \mathrm{bc}$ & $14.97 \mathrm{a}$ & $323.88 \mathrm{a}$ & $16.23 \mathrm{ab}$ & $19.96 \mathrm{ab}$ \\
$\mathrm{AF}$ & $(2.3)$ & $(1.44)$ & $(0.78)$ & $(1.57)$ & $(1.31)$ & $(1.58)$ \\
& $407.41 \mathrm{c}$ & $27 \mathrm{c}$ & $15.07 \mathrm{a}$ & $318.55 \mathrm{a}$ & $14.2 \mathrm{a}$ & $22.35 \mathrm{ab}$ \\
$\mathrm{NF}$ & $(1.60)$ & $(1.50)$ & $(0.93)$ & $(1.26)$ & $5(1.00)$ & $(1.41)$ \\
\hline
\end{tabular}

Note: SD: S. discolor (Champ. ex Benth.) Muell.; CF: C. fargesii Franch. ; CM: C.myrsinifolia (Blume) Oersted; MP: M. pauhoi Kanehira; AF: A. fortunei (Hemsl.) Makino; VF: V. fordii (Hemsl.) Airy Shaw.

\subsection{Distribution of $C$ and $N$ in different soil layers and their ecological stoichiometry}

As shown in Table 5, the total $\mathrm{C}$ and $\mathrm{N}$ decreases with soil depth. With the increase of soil depth, the contents of soil SOC, ROC, total $\mathrm{N}$, alkali nitrogen, $\mathrm{NH}_{4}^{+}-\mathrm{N}$ and $\mathrm{NO} 3-\mathrm{N}$ in the study area decreased, but changes in $\mathrm{NH}_{4}{ }^{+}-\mathrm{N}$ and $\mathrm{NO}_{3}-\mathrm{N}$ were minor. At 0-10 cm soil depth, the total $\mathrm{N}$, alkali nitrogen, $\mathrm{NO}_{3}-\mathrm{N}$ and $\mathrm{C}: \mathrm{N}$ ratio had a significant $\mathrm{CV}$; at $10-20 \mathrm{~cm}$ soil depth, the $\mathrm{CV}$ of ROC, alkaline nitrogen and $\mathrm{NO}_{3}-\mathrm{N}$ were significant. In general, the horizontal spatial heterogeneity of soil $\mathrm{C}$ and $\mathrm{NH}_{4}{ }^{+}-\mathrm{N}$ levels in the study area was not obvious, whereas the horizontal spatial distribution of soil $\mathrm{NO}_{3}-\mathrm{N}$ content was significantly heterogeneous.

Table 5. Distribution and stoichiometry of soil carbon and nitrogen at different depths in evergreen broadleaved forest in Dagangshan Mountain, Jiangxi Province

\begin{tabular}{cccccccc} 
Depths & SOC & ROC & N & $\begin{array}{c}\text { Alkaline } \\
\text { N }\end{array}$ & NH4+-N & NO3--N & C:N \\
& & & & & & \\
$\mathrm{g} / \mathrm{kg}$ & $\mathrm{g} / \mathrm{kg}$ & $\mathrm{g} / \mathrm{kg}$ & $\mathrm{mg} / \mathrm{kg}$ & $\mathrm{mg} / \mathrm{kg}$ & $\mathrm{mg} / \mathrm{kg}$ & \\
\hline
\end{tabular}




\begin{tabular}{|c|c|c|c|c|c|c|c|}
\hline $0-10$ & $\begin{array}{l}20.06 \\
(1.38)\end{array}$ & $\begin{array}{l}15.24 \\
(0.43)\end{array}$ & $\begin{array}{c}1.46 \\
(0.28)\end{array}$ & $\begin{array}{c}70.73 \\
(25.67)\end{array}$ & $\begin{array}{c}1.72 \\
(0.11)\end{array}$ & $\begin{array}{c}3.19 \\
(2.01)\end{array}$ & $\begin{array}{l}14.21 \\
(3.70)\end{array}$ \\
\hline $10-20$ & $\begin{array}{l}12.73 \\
(0.89)\end{array}$ & $\begin{array}{c}6.13 \\
(1.14)\end{array}$ & $\begin{array}{c}0.72 \\
(0.08)\end{array}$ & $\begin{array}{l}36.47 \\
(6.47)\end{array}$ & $\begin{array}{c}1.57 \\
(0.11)\end{array}$ & $\begin{array}{c}3.07 \\
(1.80)\end{array}$ & $\begin{array}{l}17.75 \\
(0.72)\end{array}$ \\
\hline
\end{tabular}

Note: ** is significantly correlated at the 0.01 level, ${ }^{*}$ significantly correlated at the 0.05 level.

\subsection{Correlation between $C$ and $N$ distribution and ecological stoichiometry}

As shown in Tables 6 and 7, soil SOC in the study area was positively correlated with soil alkaline nitrogen at 0-10 cm soil depth. On the other hand, at 10-20 cm soil depth, soil ROC was positively correlated with soil $\mathrm{NO}_{3}-\mathrm{N}$; soil SOC was positively correlated with soil total N; soil ROC was negatively correlated with soil total N; Soil ROC was significantly positively correlated with soil $\mathrm{NH}_{4}{ }^{+}-\mathrm{N}$; soil alkaline nitrogen and soil C:N ratio were also positively correlated.

Table 6. Correlative coefficient matrix between carbon and nitrogen distribution and eco-stoichiometric ratio in $0-10 \mathrm{~cm}$ soil

\begin{tabular}{|c|c|c|c|c|c|c|c|}
\hline $0-10$ & SOC & ROC & $\mathbf{N}$ & $\begin{array}{c}\text { Alkaline } \\
\mathbf{N}\end{array}$ & $\mathrm{NH}^{+}-\mathrm{N}$ & $\mathrm{NO}^{-}-\mathrm{N}$ & C:N \\
\hline SOC & 1 & 0.110 & 0.576 & 0.463 & $0.724^{*}$ & -0.052 & 0.208 \\
\hline ROC & & 1 & -0.308 & 0.067 & 0.340 & 0.197 & 0.155 \\
\hline $\mathrm{N}$ & & & 1 & 0.237 & 0.430 & -0.086 & 0.444 \\
\hline $\begin{array}{c}\text { Alkaline } \\
\mathrm{N}\end{array}$ & & & & 1 & 0.575 & -0.637 & 0.019 \\
\hline $\mathrm{NH}_{4}{ }^{+}-\mathrm{N}$ & & & & & 1 & -0.095 & 0.124 \\
\hline $\mathrm{NO}_{3}-\mathrm{N}$ & & & & & & 1 & 0.136 \\
\hline $\mathrm{C}: \mathrm{N}$ & & & & & & & 1 \\
\hline
\end{tabular}

Table 7. Correlative coefficient matrix between carbon and nitrogen distribution and eco-stoichiometric ratio in $10-20 \mathrm{~cm}$ soil

\begin{tabular}{cccccccc}
\hline 10-20 & SOC & ROC & $\mathbf{N}$ & $\begin{array}{c}\text { Alkaline } \\
\mathbf{N}\end{array}$ & NH4+-N & NO3- $-\mathbf{N}$ & C:N \\
\hline SOC & 1 & -0.061 & $0.824^{* *}$ & 0.307 & 0.061 & -0.232 & -0.151 \\
& & & & & & & \\
ROC & & 1 & $-0.587^{*}$ & -0.108 & $0.787^{* *}$ & 0.560 & 0.109
\end{tabular}




\begin{tabular}{|c|c|c|c|c|c|}
\hline $\mathrm{N}$ & 1 & 0.385 & -0.395 & -0.481 & -0.093 \\
\hline $\begin{array}{c}\text { Alkaline } \\
\mathrm{N}\end{array}$ & & 1 & 0.080 & -0.175 & $0.591^{*}$ \\
\hline $\mathrm{NH} 4+-\mathrm{N}$ & & & 1 & 0.437 & 0.187 \\
\hline NO3- - N & & & & 1 & 0.039 \\
\hline C:N & & & & & 1 \\
\hline
\end{tabular}

\section{Discussion}

\section{1. $C$ and $N$ contents and their ecological stoichiometry in different plant parts}

As shown in Table 2, the CV of the average $\mathrm{N}$ content in fine roots and litter was as high as $13.33 \%$ and $16.22 \%$, respectively, indicating that there is a large degree of spatial distribution of total $\mathrm{N}$ content in the fine roots of different tree species in the study area. Since the major pathways for $\mathrm{C}$ assimilation, photosynthesis and nutrient absorption are different pathways, $\mathrm{C}$ is usually not a limiting element of plant growth, and thus $C$ content has a small variation in most plants [12].

Studies have shown that the total $\mathrm{C}$ and $\mathrm{N}$ content of the leaves of 102 dominant plants in southeastern China ranges from 374.1 to $646.5 \mathrm{~g} / \mathrm{kg}$ and 8.4 to $30.5 \mathrm{~g} / \mathrm{kg}$, respectively [13]. In this study, we measured the leaf $\mathrm{N}$ content of six representative species of evergreen broad-leaved forest in the study area and found the average values were consistent with the values of the dominant plant leaves in the eastern and southern transects. The average $C$ content was $401.87 \mathrm{~g} / \mathrm{kg}$, which was lower than that of 492 terrestrial plants worldwide $(464 \mathrm{~g} / \mathrm{kg}$ ) [14]. This may be explained by the fact that our sample collection was done in autumn, a season when plants are not as metabolically active and the turnover rate is not as high as during other seasons. The average content of leaf $\mathrm{N}$ in the six representative trees was $21.41 \mathrm{~g} / \mathrm{kg}$, which was slightly higher than the global average content of $\mathrm{N}$ in plant leaves $(20.09 \mathrm{~g} / \mathrm{kg})$ [13]. This value however was higher than one in 753 Chinese terrestrial plants $(18.6 \mathrm{~g} / \mathrm{kg})$ [15]. This may be related to the high resorption rate of leaf $\mathrm{N}$, thus promoting nitrogen retention and reuse of $\mathrm{N}$ and enlarging the leaf $\mathrm{N}$ pool. Previous studies have shown the average content of $C$ and $\mathrm{N}$ in fine roots of Chinese terrestrial plants to be $473.9 \mathrm{~g} / \mathrm{kg}$ and $9.16 \mathrm{~g} / \mathrm{kg}$, respectively. The latter value is within the range of global average root $\mathrm{N}$ content $(9.90-11.2 \mathrm{~g} / \mathrm{kg})$. The worldwide data also showed that fine root $\mathrm{N}$ content and soil nutrients are positively correlated [16]. The average content of fine root $\mathrm{N}$ in our six species was $15.73 \mathrm{~g} / \mathrm{kg}$, which was higher than the fine root $\mathrm{N}$ content of both terrestrial plants both in China and globally, indicating that the study area in Dagangshan is an area with high concentrations of root and soil N.

Carbon and nitrogen are indispensable elements for plant growth and development: carbon is the most important element in plant dry matter, while nitrogen is a limiting element in plant growth [17-18]. Furthermore, understanding the characteristics of leaf $C$ and $N$ and their spatial distribution pattern can help us to evaluate the primary productivity of ecosystems. Among the six representative species we studied, $S$. discolor contained the highest amount of leaf $\mathrm{C}$ and the highest root $\mathrm{N}$ content, indicating that its carbon and nitrogen storage capacities are remarkable. We can infer from this that S. discolor is a pioneer species of secondary bare land in the region. These data are also indicative of the rate of nutrient cycling rate and efficiency of the forest ecosystem.

As a main element in chlorophyll, $\mathrm{N}$ affects plant chlorophyll activity, photosynthetic rate, enzymatic activities during dark reactions, and photorespiration rate [19]. The rate of respiration is related to the amount of $\mathrm{N}$ in plant tissues [20]. In plant cells, $90 \%$ of $\mathrm{N}$ is present in proteins, and 
these proteins need energy to self-repair [21]. The $\mathrm{N}$ content and its ratio in plants are strong indicators of the internal stability of the elements in plants. The contents of $\mathrm{C}$ and $\mathrm{N}$ in leaves and fine roots of six different plants in the evergreen broad-leaved forest in Dagangshan were generally consistent, showing a positively correlating relationship (i.e., if the content of $\mathrm{C}$ is abundant, then the content of $\mathrm{N}$ is also abundant and vice versa). By comparing the $\mathrm{C}: \mathrm{N}$ ratios of the leaves and fine roots of different tree species, we found that when the $\mathrm{C}: \mathrm{N}$ ratio is higher, the $\mathrm{N}$ content is less abundant. Among the six species we studied, C. fargesii, C. myrsinifolia, A. fortunei and V. fordii contained higher leaf $\mathrm{N}$ content than root $\mathrm{N}$ content, and the ratio of root $\mathrm{N}$ to $\mathrm{C}$ is higher than that of leaf $\mathrm{N}$ to $\mathrm{C}$, suggesting these species have a high nitrogen transfer rate. By contrast, for $S$. discolor and M. pauhoi, the content of root $\mathrm{N}$ is higher than that of leaf $\mathrm{N}$, which is probably due to the specific methods of nitrogen transfer and utilization in these two species. To further understand this, it is necessary to compare the element contents in various parts of the plants, thus predicting the equilibrium relationship between chemicals among multiple processes. The growth rate hypothesis suggests that the $\mathrm{C}: \mathrm{N}$ ratio has a strong regulatory effect on plant growth rate. For most organisms, the high growth rate often corresponds to a high $\mathrm{N}: \mathrm{C}$ ratio [22]. In our study, we found, consistent with the growth rate hypothesis, that $A$. fortunei had low leaf and fine root $\mathrm{C}: \mathrm{N}$ ratios, and the growth rate of this species was high. This species is a fast-growing species, and the same time a pioneer species in secondary bare land.

S. discolor, S. discolor and V. fordii are the deciduous species. C. fargesii, C. myrsinifolia and $M$. pauhoi are the evergreen species. The average $C: \mathrm{N}$ ratio of leaves and fine roots of deciduous species was smaller than evergreen trees. In the Dagangshan Mountains of Jiangxi Province, the study of 16 common tree species, in natural evergreen broad-leaved forests, revealed that in the vertical structure of the main canopy of the forest, the evergreen tree species are generally distributed in the lower layer, and the deciduous tree species are relatively distributed in the upper layer [23]. The evergreen tree species have a slow growth strategy. The above is consistent with our findings that deciduous species had low leaf and fine root $\mathrm{C}$ : $\mathrm{N}$ ratios, and the growth rate of this species was high. This survival strategy is the result of long-term adaptation of the organism to the environment, and the plant regulates the content of the elements in the body to achieve a better living state.

\subsection{Soil $\mathrm{C}$ and $\mathrm{N}$ content and their ecological stoichiometry}

Using soil samples collected from different depths, we found that the soil SOC, ROC, total N and alkali nitrogen content in our study area decreased with the increase of soil depth. A possible reason for this is that the decomposition of litter occurs on the surface layer of soil, and constantly moves downward [24-25]. The deposition, leaching, ammoniation, and denitrification of atmospheric nitrogen have great impact on the changes of soil nitrogen content [26-27]. In our study area, soil $\mathrm{NH}_{4}{ }^{+}-\mathrm{N}$ and $\mathrm{NO}_{3}-\mathrm{N}$ did not display a significant difference between 0-10 $\mathrm{cm}$ soil samples and 10-20 $\mathrm{cm}$ soil samples. This may be because the effects of ammoniation and nitrification on the content of $\mathrm{NH}_{4}{ }^{+}-\mathrm{N}$ and $\mathrm{NO}_{3}-\mathrm{N}$ in soil were greater than those of atmospheric nitrogen deposition and leaching. The soil $\mathrm{NO}_{3}-\mathrm{N}$ content in the study area was higher than that of $\mathrm{NH}_{4}{ }^{+}-\mathrm{N}$, which is consistent with the results of Song et al. [23]. In their study, the authors revealed that the soil $\mathrm{NH}_{4}^{+}-\mathrm{N}$ pool is larger in winter and spring, whereas in summer and autumn, the soil $\mathrm{NO}_{3}-\mathrm{N}$ pool is larger.

Alkaline $\mathrm{N}$ is an important indicator of the level of $\mathrm{N}$, and it can accurately reflect soil $\mathrm{N}$ dynamics and $\mathrm{N}$ supply levels in an organism [28]. At 0-10 cm soil depth, the soil SOC in the study area was positively correlated with the alkaline $\mathrm{N}$; and at 10-20 cm soil depth, the soil SOC and N were significantly positively correlated, indicating that the nitrogen supply capacity is also high when the soil carbon content is abundant. ROC is an important part of soil active organic carbon, which can sensitively reflect changes in soil quality [29]. It may have certain effects on soil microbes, thus affecting the positive correlation between ammoniation rate and soil $\mathrm{NH}_{4}{ }^{+}-\mathrm{N}$ content.

\section{Conclusion}

(1) The average $C$ and $N$ contents in the leaves, fine roots and litter were significantly different from the average content of soil. The CV of the average $\mathrm{N}$ contents of fine roots (13.29\%) and litter 
$(16.22 \%)$ in the 6 representative tree plants were larger than that of $C$, indicating that the spatial distribution of total $\mathrm{N}$ content of fine roots of the different tree species in the study area is larger. The $\mathrm{C}: \mathrm{N}$ ratio of litter is greater than the average leaf $\mathrm{C}: \mathrm{N}$ ratio, which is probably due to the reabsorption of $\mathrm{N}$ nutrients by plant leaves (note the average resorption rate of $\mathrm{N}$ is $40.40 \%$ ).

(2) The $\mathrm{C}$ and $\mathrm{N}$ contents in the leaves and fine roots of $\mathrm{S}$. discolor were high, so its carbon and nitrogen storage capacity is strong. A. fortunei had low leaf and fine root $\mathrm{C}: \mathrm{N}$ ratios, and the growth rate of this species was high. This species is a fast-growing species, and at the same time a pioneer species in secondary bare land. Compared with deciduous species, the evergreen tree species have a slow growth strategy. A. fortunei had high leaf and fine root $\mathrm{C}: \mathrm{N}$ ratios, and the growth rate of this species was accordingly low.

(3) The changes in the contents of $\mathrm{C}$ and $\mathrm{N}$ in leaves and fine roots of six different plant species in the evergreen broad-leaved forest were generally consistent, featuring a positive correlation; In different plant parts, if the C:N ratio was higher, the $\mathrm{N}$ content was less abundant. Among the six species we studied, four species (C. fargesii, C. myrsinifolia, A. fortunei, and V. fordii) contain higher leaf $\mathrm{N}$ content than fine root $\mathrm{N}$ content, suggesting these species have a high nitrogen transfer rate.

(4) With the increase of soil depth, the contents of soil SOC, ROC, total N, alkali nitrogen, $\mathrm{NH}_{4}{ }^{+}-$ $\mathrm{N}$ and $\mathrm{NO}_{3}^{-}-\mathrm{N}$ in the study area decreased, but the change of $\mathrm{NH}_{4}^{+}-\mathrm{N}$ and $\mathrm{NO}_{3}^{-}-\mathrm{N}$ were minor. At $0-$ $10 \mathrm{~cm}$ soil depth, the soil SOC in the study area was positively correlated with the alkaline $\mathrm{N}$, and at 10-20 cm soil depth, the soil SOC and N were significantly positively correlated, indicating that the nitrogen supply capacity is also high when the soil carbon content is abundant.

Acknowledgements: This study was supported by the National Key Research and Development Program of China (No. 2017YFC0503804), the Evaluation Research Scheme of Forest Accounting and Green Economy Integration (2017-R11), Science and Technology Innovation \& Service Capacity Building-Collaborative Innovation Center-Forestry/Fruit Industry Ecological/Environment Function Enhancement Collaborative Innovation Center (2011 Collaborative Innovation Center, municipal level, PXM2017_014207_000024).

Author contribution: Experimental design: HW, BW, and HB; field investigation and laboratory experiments: HW, JL, HC, YL and QS; data analysis: HW, ZL and QS; drafting manuscript: HW; critical reading: $\mathrm{BW}$.

Conflict of interest: The authors declare that there is no conflict of interest.

\section{References}

1. Guirui Yu; Xuanran Li; Ning Zhao. The role of ecological chemometrics in the carbon-nitrogen-water coupled cycle theory system of terrestrial ecosystems. Quaternary Sciences 2014, 34, 881-889.

2. Jiahui Zhang, Ning Zhao, Congcong Liu. C:N:P stoichiometry in China's forests: From organs to ecosystems. Functional Ecology 2018, 32, 50-60, 10.1111/1365-2435.12979.

3. Shijie Han, Zhiyou Yuan, Yunxi Fang. Study on carbon-nitrogen coupling cycle and carbon source sink effect in forest and grassland ecosystems in northern China. Journal of Beijing Forestry University 2016, 38, 128-130.

4. Elser J J, Sterner R W, Gorokhova E, Fagan W F, Markow T A, Cotner J B, Harrison J F, Hobbie S E, Odell G M, Weider L J. Biological stoichiometry from genes to ecosystems. Ecology Letters 2000, 3, 540-550, 10.1111/j.1461-0248.2000.00185.x.

5. Bin Cheng, Yongjun Zhao, Wenguang Zhang. Progress in ecological chemometrics research. Chinese Journal of Ecology 2010, 30, 1628-1637.

6. Dehui Zeng, Guangsheng Chen. Ecological chemometrics: exploration of the mystery of complex living systems. Chinese Journal of Plant Ecology 2005, 29, 1007-1019.

7. Hessen D O, Elser J J, Sterner R W. Ecological stoichiometry: An elementary approach using basic principles, Limnology and oceanograchy 2013, 58, 2219-2236, 10.4319/lo.2013.58.6.2219.

8. Shaoqiang Wang, Guirui Yu. Ecological stoichiometry of carbon, nitrogen and phosphorus in ecosystems. Acta Ecologica Sinica 2008,28(8):3937-3947.

9. Ying Lin. Overview of Jiangxi Forest. Jiangxi Forest. China Forestry Publishing House, Beijing, China, 1986, pp. 21-77, 16425.16. 
10. Yongjing Lin, Mengjuan $\mathrm{Wu}$, Tongping Lu. Visualization analysis of hotspots in Chinese ecological chemometrics research. Journal of Ecology 2018, 2, 63-66.

11. Rukun Lu. Soil Agrochemical Analysis Method. Hohai University Press, Nanjing 1999, 9787801199251.

12. Zhaoxia Zeng, Kelin Wang, Xiaoli Liu. Study on the characteristics of soil ecological stoichiometry of karst forest plants-leaves-soil in northwestern Guangxi. Chinese Journal of Plant Ecology 2015, 39, 682-693.

13. Shujie Ren, Guirui Yu, Jiang Chunming. Statistical characteristics of carbon, phosphorus and phosphorus stomatometry of 102 dominant species in forest ecosystems in the north-south transects of eastern China. Chinese Journal of Applied Ecology 2013, 23, 581-586.

14. Elser JJ, O'Brien WJ, Dobberfuhl DR. The evolution of ecosystem processes: Growth rate and elemental stoichiometry of a key herbivore in temperate and arctic habitats. Journal of Evolutionary Biology 2000, 13, 845-853, 10.1046/j.1420-9101.2000.00215.x.

15. Han W, Fang J, Guo D, et al. Leaf nitrogen and phosphorus stoichiometry across 753 terrestrial plant species in China. New Phytologist 2005, 168, 377-385, 10.1111/j.1469-8137.2005.01530.x.

16. Yuzhu Ma, Quanlin Zhong, Bingjie Qi. Spatial variation of carbon, nitrogen and phosphorus stoichiometry of Chinese plants and its influencing factors. Chinese Journal of Plant Ecology 2015, 39, 159-166.

17. Wenhua Cheng, Zhihong Huang, Wende Yan. Summary of carbon-nitrogen cycle function coupling research in forest ecosystems. Acta Ecologica Sinica 2006, 26, 2365-2371.

18. Ying Wang, Shuying Liu, Ping Wang. Changes of soil active Organic Carbon Pool in Qinwangchuan Irrigation District under Different Land Use Patterns. Journal of Arid Land Resources and Environment 2014, 28, 103-108.

19. Xuefeng Ma, Wei Gao, Zhijun Cheng. Advances in Molecular Mechanisms of Plant Nitrogen Absorption and Utilization. Crops 2013, 4, 32-38.

20. McGroddy ME, Daufresne T, Hedin LO. Scaling of C: N: P stoichiometry in forests worldwide: implications of terrestrial Redfield-type ratios. Ecology 2004, 85, 2390-2401, 10.1890/0012-9658(2008)89[890:E]2.0.CO;2.

21. Elser JJ, Acharya K, Kyle M. Growth rate-stoichiometry couplings in diverse biota. Ecology letters 2003, 6, 936-943, 10.1046/j.1461-0248.2003.00518.x.

22. Wenxia Zhao. (Beijing Forestry University, Beijing, China). Research for leaf, stem and root function traits for common tree species in subtropical evergreen broad-leaved forest, 2016.

23. Jones M B, Leafe E L, Stiles W. Pattern of respiration of a perennial ryegrass crop in the field. Annals of Botany, 1978, 42: 693-703, 10.1093/oxfordjournals.aob.a085504.

24. Qingni Song, Qingpei Yang, Dingkun Xu. Effects of subtropical forest conversion on soil nitrogen mineralization and availability in central Yunnan. Acta Ecologica Sinica 2013, 33, 7309-7318.

25. Li Rad. (Central South University of Forestry and Technology, Hunan, China) The stoichiometric characteristics of plant carbon, nitrogen and phosphorus in leaves of different degraded forests in Central Asia, 2017.

26. Baorong Wang, Quanchao Zeng, Qishan An. Soil-leaf-soil ecological stoichiometry of two natural secondary forests in the high-atomic Wuling forest area of Loess Plateau. Acta Ecologica Sinica 2017, 37, 5461-5473.

27. Guohong Lü, Guangsheng Zhou, Li Zhou. Seasonal dynamics of soil alkaline nitrogen and dissolved organic carbon in reed community of Panpanjin wetland. Journal of Meteorology and Environment 2006, 22, 59-63.

28. Shuiqing Zhang, Shan Lin, Doudou Guo. Relationship between total nitrogen and alkali nitrogen content and nitrogen input in fluvo-aquic soil under long-term fertilization. China Soil and Fertilizer 2017, 6, $23-26$.

29. Xue Zhang, Shiji Han e, Shuqi Wang. Changes of soil organic carbon components in different succession stages of birch forest in Changbai Mountain. Journal of Ecology 2016, 35,282-289. 